\title{
Turisztikai célú támogatás hatásának vizsgálata a vállalati versenyképességre
}

\section{Monitoring of the Corporate Competitiveness Effect of Tourism Support}

\author{
T. NAGY1 ${ }^{1}$ É. DARABOS 2 \\ ${ }^{1}$ Debreceni Egyetem, Gazdaságtudományi Kar, Számviteli és Pénzügyi Intézet, nagy.tunde@econ.unideb.hu \\ 2Debreceni Egyetem, Gazdaságtudományi Kar, Számviteli és Pénzügyi Intézet, darabos.eva@econ.unideb.hu
}

\begin{abstract}
Absztrakt. A turizmus ma a világon kétség kívül stratégiai fontosságú. Magyarország esetében is elmondható, hogy nagymértékben járul hozzá a gazdaság teljesítményéhez, valamint a foglalkoztatásban betöltött szerepe sem vitatható. A nemzetgazdasági súlyából adódóan mindenképpen elemzésre alkalmas területet jelent, azonban az összetettségből adódóan gazdasági teljesítményének, versenyképességének számbavétele rendkívül bonyolult feladat. A két közvetlenül leginkább kapcsolódó ágazat, a szálláshely-szolgáltatás és vendéglátás teljesítményén keresztül mérhetô leginkább. Jelen tanulmány nem is szándékozik a turisztikai ágazat egészének teljesítményét mérni, célja vállalati oldalról, a vállalati versenyképesség számviteli adatokból mérhetố, egy részterületének a vizsgálata. A konkrét vizsgálat tárgya 8 turisztikai célú támogatást kapott vállalat jövedelmezôségi helyzete.
\end{abstract}

Abstract. Today the tourism is without doubt strategic of importance in the world. In Hungary's case can be related, that contributes to the performance of the economy largely, and its role is very important in the employment, too. Because of national economic weight it is suitable to analysing, but for the sake of complexity the consideration of economic performance, competitiveness exceptionally complicated task. The two sections are attached most directly, the performace is measurable through the accomodation service and hospitality. Present study does not intend to measure the performance of whole tourism section, the aim is from a corporate side, measure the corporate competitiveness from accountancy datas, the examination of part. The object of the actual examination is monitoring of the profitability effect of tourism supports through the example of 8 companies.

\section{Bevezetés}

A turizmus ágazat több szempontból is különleges a gazdasági ágazatok között. Például korántsem tekinthető egységnek. Sokkal inkább egy sajátos piac, ahol különböző ágazatok kínálata találkozik a turisztikai kereslettel (KULENDRAN-WILSON, 1989). Diamond sem tekinti egységes ágazatnak a turizmust, hangsúlyozza más ágazatokkal való kapcsolatát. A turizmus ágazatba azok a tevékenységek tartoznak, melyek közvetlenül képesek hatást gyakorolni a turisztikai keresletre, illetve elsődleges céljuk ennek 
kielégítése. A turizmus ágazat úgynevezett „turisztikai alapszolgáltatásokat” foglal magába, mint például a szállásadás, míg a turizmus-gazdaság a turizmus multiplikáló hatását is figyelembe veszi, olyan, nem „alap” szolgáltatásokat is magába foglal, melyek csak közvetve kapcsolódnak a turisztikai kereslet kielégítéséhez (DIAMOND, 1977).

Jelentősége fokozatosan nő, a turizmus ma a világon kétség kívül stratégiai fontosságú ágazat. Magyarország esetében is elmondható, hogy nagymértékben járul hozzá a gazdaság teljesítményéhez, valamint a foglalkoztatásban betöltött szerepe sem vitatható. A KSH adatai szerint 2018-ban a turizmus közvetlen hozzájárulása hazánk GDP-jéhez 6,8\%-os volt, a közvetett hatásokat is figyelembe véve ez a hozzájárulás elérte a 10,7\%-ot. Ebben az évben a turisztikai szektorban 428 ezer fő dolgozott, az álláshelyek számának 10 \%-a volt köthető közvetlenül ehhez az ágazathoz $\left(I_{1}\right)$. A turisztikai ágazat teljesítményének növekedését az is jól reprezentálja, hogy 2018-ban a vendég éjszakák száma 11\%-kal emelkedett 2017-hez viszonyítva. A kereskedelmi szálláshelyek pedig 15\%-kal több bevételt realizáltak az előző évhez mérve $\left(I_{1}\right)$. Az Unió tagjaként 2004-től jelentős források váltak pályázhatóvá hazánk számára, a Nemzeti Fejlesztési Terv keretében 5 operatív programhoz kapcsolódóan több mint 60 különböző pályázat indult. A Regionális fejlesztés Operatív Program keretében jelentős támogatási összegek érkeztek az Észak-alföldi Régió turizmusának fejlesztése céljából is, hiszen ez az ágazat kitörési pontot jelent a régió számára. 2007 és 2013 között a vidékfejlesztési támogatásokkal együtt 8000 milliárd eurós uniós támogatásban részesült hazánk annak érdekében, hogy felzárkózhasson a fejlett országokhoz. A 2014-2020 közötti időszakban már nem a leszakadt régiók felzárkóztatása az elsődleges prioritás. A Széchenyi 2020 keretösszege 7500 milliárd forint, majdnem eléri a 2007-2013 között rendelkezésre álló Európa Uniós forrást $\left(I_{2}\right)$.

A nemzetgazdasági súlyából adódóan mindenképpen elemzésre alkalmas területet jelent a turizmus, azonban az összetettségből adódóan gazdasági teljesítményének, versenyképességének számbavétele rendkívül bonyolult feladat. A két közvetlenül leginkább kapcsolódó ágazat, a szálláshely-szolgáltatás és vendéglátás teljesítményén keresztül mérhető leginkább. Jelen tanulmány nem is szándékozik a turisztikai ágazat egészének teljesítményét mérni, célja vállalati oldalról, a vállalati versenyképesség számviteli adatokból mérhető, egy részterületének a vizsgálata. A konkrét vizsgálat tárgya 8 turisztikai célú támogatást kapott vállalat jövedelmezőségi helyzete.

\section{A versenyképesség fogalmi megközelítései, egyes szintjei}

A versenyképesség fogalmi meghatározása során több megközelítéssel találkozhatunk. Ezek közül az egyik a közgazdasági értelmezés. Képviselője többek között Smith, Ricardo, Hechscher, Ohlin, Krugman. Versenyképesség alatt jellemzően a nemzetgazdaság nemzetközi viszonyulásait, exportpiaci részesedését értették, a nemzetközi kereskedelem alakulását befolyásoló tényezőket vizsgálták. Komparatív előnyök, valamint a keresleti és kínálati oldali tényezők szempontjából közelítették meg a fogalmat. A következő táblázat összefoglalóan mutatja be az egyes fogalmi alapokat. 


\begin{tabular}{|l|l|}
\hline \multicolumn{1}{|c|}{ Képviselő } & \multicolumn{1}{|c|}{ Fókuszterület, kulcsszavak } \\
\hline Adam Smith & $\begin{array}{l}\text { abszolút előny, mely adott országnak egyes termékek előállításában a } \\
\text { munkatermelékenység, illetve a költségek színvonala terén biztosít előnyt } \\
\text { más országgal szemben }\end{array}$ \\
\hline Ricardo & $\begin{array}{l}\text { komparatív előny, adott ország termékek előállításában a relatív } \\
\text { munkatermelékenység, és a relatív ráfordításköltségek kapcsán biztosít } \\
\text { előnyt a nemzetközi kereskedelemben, más országokkal szemben }\end{array}$ \\
\hline Heckscher és Ohlin & $\begin{array}{l}\text { komparatív előny, adott ország akkor juthat hozzá a nemzetközi } \\
\text { kereskedelemben, ha a termékek relatíve eltérő tényező igényességét } \\
\text { (munkaintenzív vagy tőkeintenzív jelleg) figyelembe véve, olyan termékeket } \\
\text { elóállítására szakosodik, melyekhez viszonylag bőven } \\
\text { állnak rendelkezésre tényezők }\end{array}$ \\
\hline Krugman & $\begin{array}{l}\text { komparatív előny, mely az országok kölcsönösen előnyös munkamegosztási } \\
\text { megállapodása által érhető el. }\end{array}$ \\
\hline
\end{tabular}

1. táblázat. Versenyképesség közgazdasági/komparatív előnyök szerinti értelmezése

Forrás: Saját szerkesztés (SOMOGYI, 2009) alapján

A komparatív irányzat hátulütője, hogy csupán a versenyképesség kínálati oldalát veszi figyelembe, nem számol egyéb tényezőkkel, mint a kereslet, a piac működési modellje, a technológiai és beszállítói kapcsolatok tényezői.

A másik megközelítés a gazdálkodástudományi, mely Porter nevével füződik. A gazdálkodástudományi megközelítések a megfigyelhető gazdasági folyamatok és vállalati stratégiák jellemzői alapján vonnak le a versenyképességhez kapcsolódó következtetéseket. A megközelítés a vállalatok nemzetközi versenyben történő részvételét veszi alapul. A vállalatok sikerességét tekintik meghatározónak az ország sikeressége, versenyképessége esetében. Ennek az iránynak a célja nem a fogalmi pontosítás, hanem a versenyképesség javítására szolgáló javaslatok feltárása és alkalmazása. A közgazdasági komparatív előnyökkel szemben Porter kompetitív előnyökben gondolkodik, melyek a versenytársakkal szemben jelennek meg. Ez az előny a tartósan fenntartható és versenytársak által nem ellensúlyozható tényezők függvénye. Porter szerint a termelékenységre kell fókuszálni a versenyképesség esetén, lehetőség szerint iparáganként. Ennek a felfogásnak az az előnye, hogy számol azzal a ténnyel is, hogy az országok nem lehetnek minden iparágban versenyképesek (SOMOGYI, 2009). Porter külön értelmezte a nemzeti, az iparági és a vállalati versenyképességet. Ezek alapjának a költségelőnyöket és a termékdifferenciálás nyújtotta előnyöket tekintette $\left(I_{3}\right)$.

Porterhez hasonlóan Chikán Attila, a hazai versenyképességi kutatások kiemelkedő alakja is több szinten értelmezi a versenyképességet. Makró, nemzetgazdasági szinten a következőképpen fogalmazza meg: „a nemzetgazdaságnak az a képessége, hogy úgy tud létrehozni, felhasználni, illetve a globális verseny keretei között értékesíteni termékeket és szolgáltatásokat, hogy közben saját termelési tényezőinek hozadéka, s ezzel párhuzamosan állampolgárainak jóléte fenntartható módon növekszik. Ezen versenyképesség feltétele az erőforrások termelékenységnövekedésének elősegítése a vállalatok és más intézmények hatékonyságának növekedését biztosító feltételek folyamatos fenntartása útján" (CHIKÁN et al., 2006); (SOMOGYI, 2009). Mikro, vállalati szinten: „a vállalati versenyképesség a 
vállalatnak azon képessége, hogy a társadalmi felelősség normáinak betartása mellett tartósan tud olyan termékeket és szolgáltatásokat kínálni a fogyasztóknak, amelyeket azok a versenytársak termékeinél (szolgáltatásainál) inkább hajlandók a vállalat számára nyereséget biztosító feltételek mellett megfizetni. Ezen versenyképesség feltétele, hogy a vállalat legyen képes a környezeti és a vállalaton belüli változások érzékelésére és az ezekhez való alkalmazkodásra a versenytársaknál tartósan kedvezőbb piaci versenykritériumok teljesítésével" (CHIKÁN et al., 2006); (SOMOGYI, 2009).

\section{Pénzügyi mutatókkal történő versenyképesség mérés}

Az üzleti teljesítmény mérése és értékelése elengedhetetlen a vállalkozás tulajdonosai, a befektetők, a piaci partnerek és a munkavállalók szempontjából egyaránt. Az üzleti teljesítmény mérhető a pénzügyi mutatók segítségével a piaci részesedés változása, az erőforrások kihasználtsága, a nyereség és az árbevétel változása révén. Az évente közzétett, nyilvánosan elérhető pénzügyi beszámolók alapján a pénzügyi mutatószámokkal mérhetővé és összehasonlíthatóvá válik az üzleti teljesítmény.

A versenyképességet meghatározó gazdálkodási hatékonyság pénzügyi mutatószámokon keresztül hasonlítható össze a leginkább, hiszen a versenyhelyzet erősödése az üzleti teljesítményt befolyásolja. A mutatószámok egyfajta, tömörített numerikus adatok, amelyek a beszámolók koncentrált formáját jelentik és ennek megfelelően értelmezhető betekintést nyújtanak a vállalkozás helyzetéről, a gazdasági összefüggésekről (KRESALEK, 2005).

\subsection{Területei}

A pénzügyi mutatókkal a vagyoni, pénzügyi és jövedelmezőségi helyzetére kapunk rálátást. A vagyoni helyzet elemzésekor jellemzően

- az eszközök és források összetételét,

- az eszközök és források lejárati összhangját,

- a vagyon változását,

- kiemelt mérlegtételek egymáshoz való viszonyát vizsgálják.

A pénzügyi helyzet kapcsán viszonyszámokkal, mutatókkal vizsgálható

- az adósságállomány, a hosszú lejáratú fizető- és hitelképesség,

- a rövid lejáratú fizetőképesség, a likviditás,

- a forgási sebessége, a futamidők.

A jövedelmezőségi helyzet esetében pedig

- a bevételek, hozamok, költségek, ráfordítások és az eredmény összetételét,

- a bevételek, hozamok, költségek, ráfordítások és az egyes eredménykategóriák változását,

- a különféle vetítési alapokon értelmezett jövedelmezőség alakulását,

- kiemelt eredménykimutatás és mérlegtételek egymáshoz való viszonyát vizsgálják. 


\subsection{Módszertana}

A rendelkezésre álló mérleg-, illetve eredménykimutatás-adatokat vertikálisan és horizontálisan elemezhetjük (FENYVES, 2014). Vertikális elemzéskor mindig a könyvviteli mérleg azonos oldaláról, vagy az eredménykimutatásból származnak az adatok, azaz a vertikális elemzés az eszközök, források, illetve a bevételek, ráfordítások belső szerkezetének feltárására alkalmasak (BÍRÓ et al., 2012). Horizontális elemzéskor pedig az összehasonlított adatok a mérleg különböző oldaláról vagy a mérlegből és az eredménykimutatásból származnak.

A vertikális és horizontális elemzés egyaránt végezhető viszonyszámok segítségével. A viszonyszámok mindig két statisztikai adat hányadosát jelentik (ÁCS-PINTÉR, 2011). Az alábbi formában fejezhetőek ki: $V=\frac{A}{B} * 100$.

V: a képzett viszonyszám

A: viszonyított adat

B: viszonyítás alapja

A viszonyszámok lehetnek:

- dinamikus,

- megoszlásai, valamint

- koordinációs viszonyszámok.

A dinamikus viszonyszámok az adat időbeli alakulásának vizsgálatát teszik lehetővé. A viszonyítás alapjául szolgáló adat alapján a dinamikus viszonyszámokon belül megkülönböztetünk lánc-és bázisviszonyszámokat. A bázisviszonyszámok nevezője minden időszakban állandó, azaz a bázisidőszakhoz viszonyítva szemlélteti az eltérést. Ezzel szemben a láncviszonyszámok a tárgyidőszaki adatot mindig az előző időszaki adathoz viszonyítják, azaz ahhoz képest lesz látható a változás. A megoszlási viszonyszámok létrehozásakor mindig a részsokaság adatát viszonyítjuk a fősokaság adatához, így ezek a viszonyszámok az egyes mérlegfőcsoportok, mérlegcsoportok, illetve bevételek, ráfordítások belső szerkezetének vizsgálatára alkalmasak (HUNYADI-VITA, 2008). A koordinációs viszonyszámok két részsokaság adatát viszonyítják egymáshoz. A vagyoni, pénzügyi, jövedelmezőségi helyzethez kapcsolódóan ezek mindig horizontális viszonyszámok, azaz vegyesen használnak adatokat a mérleg két oldaláról, illetve az eredménykimutatásból (ADORJÁN et al., 2004).

\subsection{Nehézségei}

A mutatókkal történő elemzések problémákat vetnek fel, mivel eltérések mutatkoznak az elvárt ismeretigények és az elemzés eredményeiből adódó ismeretek között. Ez az eltérés jelentős a mérleg és eredménykimutatatás elemzés esetében, ami a módszer problémáját is jelenti. Korlátozó tényezők lehetnek a következők:

1. A legjelentősebb korlátozó tényező a vállalkozásokhoz kapcsolható információs források (számviteli beszámolók) hiányossága. A háttérben meghúzódó legjelentősebb ok, hogy ezek a források befolyásolhatók. A számviteli törvény szerint választható készítési eljárások nem 
egyértelműen nevesítik a vállalat helyzetének bemutatását. A beszámolók értékelő összehasonlítása érdekében minden vállalkozás esetében ismerni kellene a konkrétan alkalmazott mérlegkészítési és értékelési eljárásokat, így a kiegészítő mellékletben és az üzleti jelentésben foglaltakat.

2. Továbbá a mérlegelemzés alapjául szolgáló információs források nem teljes körűek. Az éves beszámoló számszerű adatokat tartalmaz, kvalitatív információkat csak korlátozott mértékben a mérleg és az eredménykimutatásban és a kiegészítő mellékletben közöl (FENYVES et al., 2018).

3. Szintén nem teljes körű a rögzített gazdasági események köre.

4. A mérlegelemzés korlátja az információforrások jövőorientáltságának hiánya. A beszámolók adatai múltbéliek, így a jövőbeni fejlődést szolgáló prognosztizálás nem valósul meg. A mérleg és az eredménykimutatás tervadatokat nem tartalmaz, kizárólag az üzleti év gazdasági eseményeit. Emellett hosszabb idő telik el a mérlegkészítés és a közzétételi időpont között, az elemzés így csupán egy vélelmezett jövőkép lehet.

A létrejövő mutatószámok egy-egy értéket jelentenek, önmagukban tehát nem alkalmasak hosszú távú következtetések levonására. Számos esetben szükség van az egyedi befolyásoló tényezők és azok egymás közötti viszonyának feltárására, amit a mutatószám rendszerek alkalmazásával lehet elérni.

$\mathrm{Az}$ elemzéshez használt lehetőségek módszertani szempontjai is problémát jelenthetnek. $\mathrm{Az}$ összehasonlítás esetében leginkább az előző vagy a bázis évet használják fel. A dinamikus összehasonlítás során más vállalatok adatait, ágazati átlagot is használhatnak összehasonlításként, mint térbeli viszonyítás. Ezekben az esetekben a megbízhatóság azért kérdőjelezhető meg, mert a különféle vállalati beszámolók eltérő normákat, szubjektív megközelítéseket is tartalmazhatnak a kötelező elemek mellett, azokon belül.

A fenti problémák orvoslása akkor lenne lehetséges, ha egységes, előre átgondolt elemzési módszereket, - esetleg újakat- alkalmaznak. Az elemzési módszerek kiválasztása a korlátok ismeretében már előre, az információs igények jelentkezésekor megtörténne.

További problémát jelent a mutatószámokkal történő elemzés során, hogy azok jellemzően csak a hazai számviteli elvek mentén történnek, a nemzeti, nemzetközi megítélést a sajátos jelleg miatt nem teszik lehetővé. Bár a magyar számviteli elvek tükrözik az Uniós elveket, az elemzésekben mégis eltérések mutatkoznak nemzeti szinten. Felmerül a kérdés, hogy a gyakorlatban alkalmazott elemzési módszerek hogyan közelíthetők egymáshoz. A számvitel nemzetközi szintű szabályozásánál három alapvető rendszer ismert. Az Európai Unió számviteli irányelvei, a Nemzetközi Pénzügyi Beszámolási Standardok (IFRS) és az Általánosan Elfogadott Számviteli Alapelvek az Egyesült Államokban (US GAAP). A számviteli rendszerek közelítési igénye megjelenik több nemzetközi szinten, a számviteli információs rendszerre épülő elemzési lehetőségek területe azonban jellemzően nem része ezeknek. (KRESALEK, 2005).

\section{Az elemzett adatbázis forrása, az elemzett mutatószámok, pályázati adatok}

A 8 turisztikai célú támogatást kapott vállalat jövedelmezőségi helyzetének értékeléséhez a 2008-2018. évre vonatkozó éves beszámolók adatait használtuk fel. A vállalatok éves beszámolói az Igazságügyi 
Minisztérium Céginformációs és az Elektronikus Cégeljárásban Közreműködő Szolgálat honlapjáról származnak. Valamennyi vállalat Zrt. formában működik, eredménykimutatását összköltség eljárással készíti. A nyilvánosan elérhető adatok mellett belső vállalati nyilvántartási rendszerből származó adatok is felhasználásra kerültek.

Az egyes eredménykategóriák értékének időbeli alakulását szemléltető dinamikus viszonyszámok mellett a koordinációs viszonyszámok segítségével tovább mélyíthető a vállalatok jövedelmezőségi helyzetének elemzése. A jövedelmezőséget leíró koordinációs viszonyszámok képzésekor azt vizsgáljuk, hogy az egyes erőforrásait mennyire hatékonyan használja az adott vállalat. Bármely számviteli eredménykategória alkalmas jövedelmezőségi mutató számításra, jelen tanulmány a legnagyobb súlyt képviselő üzemi (üzleti) tevékenység eredményét tartalmazó mutatókat vizsgálja. A vetítési alapok alapján beszélhetünk árbevétel arányos, tőkearányos, eszközarányos jövedelmezőségi mutatókról. A következő táblázat a vizsgált jövedelmezőségi mutatókat, illetve azok jellegét, számítási módját összegzi.

\begin{tabular}{|l|l|l|}
\hline Megnevezés & Jellege & Számítása \\
\hline ROS- Return on sales & $\begin{array}{l}\text { bevétel arányos jövedelmezőség } \\
\text { iparág független mutató }\end{array}$ & $\begin{array}{l}\text { ÜTE/Értékesítés nettó } \\
\text { árbevétele+Egyéb } \\
\text { bevételek }\end{array}$ \\
\hline ROA- Return on assets & $\begin{array}{l}\text { eszközarányos jövedelmezőség } \\
\text { iparág független mutató }\end{array}$ & ÜTE / Összes eszköz \\
\hline ROE-Return on equity & $\begin{array}{l}\text { saját tőke arányos jövedelmezőség } \\
\text { iparág független mutató }\end{array}$ & ÜTE/Saját tőke \\
\hline
\end{tabular}

2. táblázat. Az elemzéshez alkalmazott jövedelmezőségi matatók

Forrás: Saját szerkesztés (HARANGOZÓ, 2008);(LAÁB, 2009); (MUSINSZKI, 2013); (ALMÁSI, 2018) alapján

A következő táblázat pedig az elemzett vállalatok néhány kiemelt támogatási adatát tartalmazza.

\begin{tabular}{|l|r|r|r|r|}
\hline $\begin{array}{l}\text { Vállalat } \\
\text { megnevezése }\end{array}$ & $\begin{array}{l}\text { A projekt teljes } \\
\text { költsége }\end{array}$ & $\begin{array}{l}\text { Támogatás } \\
\text { összege }\end{array}$ & $\begin{array}{l}\text { Támogatás } \\
\text { intenzitás }\end{array}$ & \multicolumn{1}{l|}{$\begin{array}{l}\text { Záró kifizetés } \\
\text { dátuma }\end{array}$} \\
\hline “A" vállalat & 6114260304 & 2750000000 & $45 \%$ & 2014.12 .17$. \\
\hline “B” vállalat & 200544573 & 139442349 & $70 \%$ & 2013.08 .14$. \\
\hline “C” vállalat & 1315920000 & 670182000 & $51 \%$ & 2014.03 .28$. \\
\hline “D” vállalat & 66933000 & 46853100 & $70 \%$ & 2014.11 .10$. \\
\hline “E" vállalat & 851267372 & 500000000 & $59 \%$ & 2013.12 .12$. \\
\hline “F” vállalat & 2000000000 & 690000000 & $35 \%$ & 2013.04 .25$. \\
\hline “G" vállalat & 714000000 & 499800000 & $70 \%$ & 2015.04 .29$. \\
\hline “H” vállalat & 447923661 & 199191652 & $44 \%$ & 2013.10 .25$. \\
\hline Összesen & 11510304337 & 4874469101 & $42 \%$ & \\
& & & & \\
\hline
\end{tabular}

3. táblázat. Az elemzéshez alkalmazott jövedelmezőségi matatók, adatok Ft-ban és \%-ban

Forrás: Saját szerkesztés belső vállalati nyilvántartások alapján 
Az elemzett 8 vállalat az Új Széchenyi Terv Fejlesztési Program Észak-alföldi Operatív Programjának azonos prioritásához kapcsolódóan (Turisztikai célú fejlesztések), azonos konstrukcióban (Szálláshelyek és szolgáltatások minőségi fejlesztése) 2011-2013 között vett igénybe Uniós támogatást. Az Új Széchenyi Terv célja a gazdaságélénkítés és munkahelyteremtés volt 2011-2013 közötti időszakra vonatkozóan. Hét kitörési pont fogalmazódott meg, (egészségipar, zöldgazdaság-fejlesztés, otthonteremtés, vállalkozásfejlesztés, közlekedésfejlesztés, tudomány-innováció és foglalkoztatás), amelyek célja a foglalkoztatás bővítése, a gazdasági növekedés feltételeinek megteremtése, Magyarország versenyképességének javítása volt, kiemelt figyelmet fordítva a hátrányos helyzetű régiók felzárkózatására. ÉAOP keretén belül 132,6 milliárd forint támogatás került kiosztásra (I4). A 8 elemzett vállalat számára összességében 4874469101 Ft támogatást folyósítottak, mely támogatási összeggel 11510304337 Ft. összköltségű beruházást valósítottak meg turisztikai területen. A támogatás intenzitása átlagosan $42 \%$-os volt.

\section{Az elemzés eredményei}

Az elemzés első lépéseként a vállalatok üzemi (üzleti) tevékenységének eredménye kerül vizsgálatra. Fontos kiemelni, hogy a jelenleg hatályos számviteli törvény szerint a kapott fejlesztési célú támogatások kétféle módon kerülhetnek elszámolásra, vagy a saját tőke javára vagy pedig egyéb bevételként, melyet időbelileg el kell határolni és az elszámolt értékcsökkenés arányos részével fel kell oldani. Jelen esetben a 8 vállalat a kapott támogatást a saját tőke javára volt köteles elszámolni, azon belül is a tőketartalékok között szerepelnek a támogatási összegek. Ilyen formában tehát közvetlenül nem befolyásolták a vállalatok látszólagos jövedelmezőségi helyzetét a kapott támogatások. A következő táblázat a 8 vállalat üzemi(üzleti) tevékenységének eredményét mutatja 2008-2018 között. Az eredménykategóriák közül csak az üzemi (üzleti) tevékenység eredménye kerül vizsgálatra, mivel valamennyi vállalat esetén elmondható, hogy a pénzügyi műveletek eredménye, illetve korábban a rendkívüli eredmény nem képviselt jelentős arányt.

\begin{tabular}{|c|c|c|c|c|c|c|c|c|}
\hline Évek & „A" & $V_{l^{\prime \prime}}{ }^{\prime \prime}$ & „B" & $V_{\text {l"B" }}$ & "C" & $\mathrm{V}_{\mathrm{l} \text { "c" }}$ & „D” & $\mathbf{V}_{\mathbf{l}^{\prime \prime} \mathbf{D}^{\prime \prime}}$ \\
\hline 2008 & 208459 & - & 18456 & - & -100556 & - & -5024 & - \\
\hline 2009 & 176701 & 85 & 17453 & 95 & -179055 & - & -8023 & - \\
\hline 2010 & 199886 & 113 & 1338 & 8 & -144883 & - & -11123 & - \\
\hline 2011 & 295638 & 148 & 8019 & 599 & -14064 & - & 14749 & - \\
\hline 2012 & 543804 & 184 & 536 & 7 & 502 & - & -24284 & - \\
\hline 2013 & 273677 & 50 & -2741 & - & 1105 & 220 & -1802 & - \\
\hline 2014 & 333164 & 122 & 11409 & - & 364 & 33 & -2513 & - \\
\hline 2015 & 584789 & 176 & 35829 & 314 & 225 & 62 & 23472 & - \\
\hline 2016 & 776952 & 133 & 19206 & 54 & 17302 & 7690 & 1934 & 8 \\
\hline 2017 & 582066 & 75 & 15016 & 78 & 4597 & 27 & 2112 & 109 \\
\hline 2018 & 540995 & 93 & 18112 & 121 & -14093 & - & 3401 & 161 \\
\hline Évek & „E” & $\mathrm{V}_{\mathrm{l} " \mathrm{E} "}$ & "F" & $\mathbf{V}_{l^{\prime \prime} \mathrm{F}^{\prime \prime}}$ & "G" & $\mathrm{V}_{\mathrm{l} \text { "G" }}$ & „H" & $\mathrm{V}_{\mathrm{I}^{\prime \prime} \mathrm{H}^{\prime \prime}}$ \\
\hline 2008 & 195207 & - & 762005 & - & 131428 & - & 116110 & - \\
\hline
\end{tabular}




\begin{tabular}{|l|r|r|r|r|r|r|r|r|}
\hline $\mathbf{2 0 0 9}$ & 494465 & 253 & 439087 & 58 & 56959 & 43 & 149241 & 129 \\
\hline $\mathbf{2 0 1 0}$ & 263558 & 53 & 694925 & 158 & 13478 & 24 & 45140 & 30 \\
\hline $\mathbf{2 0 1 1}$ & 288385 & 109 & 807687 & 116 & 22181 & 165 & 72955 & 162 \\
\hline $\mathbf{2 0 1 2}$ & 280921 & 97 & 2360065 & 292 & 16624 & 75 & 52076 & 71 \\
\hline $\mathbf{2 0 1 3}$ & 96849 & 34 & 1699491 & 72 & 15274 & 92 & -68757 & - \\
\hline $\mathbf{2 0 1 4}$ & 128926 & 133 & 2264034 & 133 & 3937 & 26 & -58300 & - \\
\hline $\mathbf{2 0 1 5}$ & 248768 & 193 & 2260275 & 100 & 22579 & 574 & -25773 & - \\
\hline $\mathbf{2 0 1 6}$ & 202370 & 81 & 6287478 & 278 & 145015 & 642 & -44280 & - \\
\hline $\mathbf{2 0 1 7}$ & 183951 & 91 & 1987758 & 32 & 105374 & 73 & -35356 & - \\
\hline $\mathbf{2 0 1 8}$ & 148788 & 81 & 3796300 & 191 & 215359 & 204 & -10384 & - \\
\hline
\end{tabular}

a4. táblázat. A vállalatok üzemi (üzleti) tevékenyének eredménye 2008-2018 között, adatok Ft-ban és \%-ban

Forrás: Saját szerkesztés a vállalatok éves beszámolói alapján

A vizsgált vállalatok közül az „A”, az ”E”, az „F” és a „G” esetében beszélhetünk jelentős összegű árbevételről, sikeres üzletmenetről. Megjegyzendő azonban, hogy mindegyik esetén jelentős eltérések mutatkoznak az egyes évek eredményei között, amit a láncviszonyszámok is jól mutatnak. Az „A” vállalat esetében 2010-től figyelhető meg növekedés, a gazdasági válság hatásai a vizsgálat első két évében egyértelműen észlelhetőek. 2012-ben magas volt az üzemi (üzleti) tevékenység eredménye - a növekvő árbevételt kisebb mértékben növekvő költségek kísérték -, majd 2013-ban újabb visszaesés történt, jelentősen csökkent, az előző időszak eredményének 50\%-ára esett vissza az eredmény. Ezt követően 2016-ig egy növekedő trend figyelhető meg, ebben az időszakban fejeződött be a részben pályázati forrásból megvalósított beruházás. 2015-ben és 2016-ban éreztette leginkább a hatását, a bővülő szolgáltatások növelték a vállalat szálláshelyadásból, vendéglátásból származó bevételeit. $\mathrm{Az}$ „E” vállalat esetében 2009 kiugró évnek tekinthető, ekkor a válság ellenére jelentős árbevétele keletkezett a cégnek. 2013-ban, a beruházások idején a vállalat szálláshely szolgáltatása és vendéglátási tevékenysége csökkentett kapacitáson működött, 66\%-os csökkenést figyelhetünk meg az üzemi (üzleti) tevékenység eredményét illetően. 2015-től csökkenő trend látható. Az „F" vállalat esetén jelentős mértékü üzemi (üzleti) tevékenység eredmény növekedés történt, 2012-re meghaladta a 2 Mrd Ft-ot, mely 192\%-os növekedést jelent az előző időszakhoz viszonyítva. 2016-ra pedig az „F” vállalat üzemi (üzleti) eredménye elérte a 6 Mrd Ft-ot. Ez az erős növekedés nem a vállalat főtevékenységéből adódott, - melyhez kapcsolódóan a támogatást igénybe vette - , a vállalat építőipari tevékenységbe kezdett. A „G” vállalat üzemi (üzleti) tevékenységének eredménye 2016-ig nem volt jelentős, ekkor szintén építőipari tevékenységbe kezdett. A további 4 vállalat esetében több évben is veszteség realizálódott, ennek megfelelően a viszonyszámok többsége nem is értelmezhető. A „B” vállalat esetén 2013 tekinthető a mélypontnak, ekkor veszteséget realizált a vállalat, majd a 2015-ben történt eredménynövekedés után már nagyságrendileg alacsonyabb eredmények keletkeztek. A „C”, „D”, „H” vállalat eredmény előállító képessége abszolút nem kielégítô, a „C” vállalat esetén 2016 tűnt olyan évnek, amikor a vállalat képes fordítani, de 2018-ban már újra vesztesége keletkezett a cégnek. A „D” vállalat esetén 2015-ban keletkezett nagyobb összegü üzemi eredmény (23 472 eFt), kiemelendő azonban, hogy az előző négy vállalat nyerségéhez viszonyítva nem tekinthető soknak. 2016-tól kezdődően a vállalat eredménye ugyan pozitív, de nagymértékben lecsökkent. A „H” vállalat esetében is hasonlóan kedvezőtlen tendencia figyelhető meg, 2009-ről 2010-re az üzemi (üzleti) tevékenység 
eredménye 70\%-kal csökkent, majd 2013-tól nagymértékű veszteséget realizált a vállalat egészen 2018ig.

A következő táblázat a vizsgált vállalatok jövedelmezőségi mutatóinak alakulását szemlélteti a 20082018 közötti időszakra vonatkozóan.

\begin{tabular}{|c|c|c|c|c|c|c|c|c|c|c|c|c|}
\hline \multirow{2}{*}{ Évek } & \multicolumn{3}{|c|}{ "A" } & \multicolumn{3}{|c|}{ „E” } & \multicolumn{3}{|c|}{ "F" } & \multicolumn{3}{|c|}{ „G" } \\
\hline & ROS & ROA & ROE & ROS & ROA & ROE & ROS & ROA & ROE & ROS & ROA & ROE \\
\hline 2008 & $7 \%$ & $3 \%$ & $6 \%$ & $57 \%$ & $6 \%$ & $7 \%$ & $7 \%$ & $3 \%$ & $7 \%$ & $60 \%$ & $31 \%$ & $36 \%$ \\
\hline 2009 & $6 \%$ & $2 \%$ & $5 \%$ & $43 \%$ & $15 \%$ & $16 \%$ & $5 \%$ & $2 \%$ & $4 \%$ & $32 \%$ & $9 \%$ & $13 \%$ \\
\hline 2010 & $6 \%$ & $2 \%$ & $5 \%$ & $58 \%$ & $8 \%$ & $9 \%$ & $7 \%$ & $2 \%$ & $5 \%$ & $10 \%$ & $2 \%$ & $3 \%$ \\
\hline 2011 & $9 \%$ & $3 \%$ & $7 \%$ & $61 \%$ & $8 \%$ & $9 \%$ & $7 \%$ & $2 \%$ & $6 \%$ & $15 \%$ & $3 \%$ & $5 \%$ \\
\hline 2012 & $15 \%$ & $5 \%$ & $12 \%$ & $58 \%$ & $7 \%$ & $9 \%$ & $21 \%$ & $7 \%$ & $15 \%$ & $15 \%$ & $2 \%$ & $4 \%$ \\
\hline 2013 & $7 \%$ & $3 \%$ & $5 \%$ & $20 \%$ & $2 \%$ & $3 \%$ & $14 \%$ & $5 \%$ & $11 \%$ & $20 \%$ & $1 \%$ & $3 \%$ \\
\hline 2014 & $9 \%$ & $3 \%$ & $6 \%$ & $21 \%$ & $3 \%$ & $4 \%$ & $18 \%$ & $6 \%$ & $13 \%$ & $3 \%$ & $0 \%$ & $1 \%$ \\
\hline 2015 & $13 \%$ & $5 \%$ & $10 \%$ & $39 \%$ & $6 \%$ & $7 \%$ & $17 \%$ & $6 \%$ & $13 \%$ & $9 \%$ & $1 \%$ & $5 \%$ \\
\hline 2016 & $17 \%$ & $7 \%$ & $12 \%$ & $32 \%$ & $5 \%$ & $6 \%$ & $46 \%$ & $16 \%$ & $34 \%$ & $44 \%$ & $8 \%$ & $23 \%$ \\
\hline 2017 & $2 \%$ & $5 \%$ & $9 \%$ & $\%$ & 0 & $6 \%$ & $\%$ & $4 \%$ & $5 \%$ & $\%$ & $5 \%$ & $14 \%$ \\
\hline 2018 & $\%$ & $5 \%$ & $7 \%$ & $9 \%$ & $3 \%$ & $4 \%$ & $16 \%$ & $6 \%$ & $9 \%$ & $57 \%$ & $10 \%$ & $23 \%$ \\
\hline \multirow{2}{*}{ Évek } & \multicolumn{3}{|c|}{ "B" } & \multicolumn{3}{|c|}{ „C" } & \multicolumn{3}{|c|}{ „D” } & \multicolumn{3}{|c|}{ „H” } \\
\hline & ROS & ROA & ROE & ROS & ROA & ROE & ROS & ROA & ROE & ROS & ROA & ROE \\
\hline 2008 & $65 \%$ & $22 \%$ & $39 \%$ & $-12 \%$ & $-4 \%$ & $-32 \%$ & $-4 \%$ & $-4 \%$ & $-4 \%$ & $6 \%$ & $5 \%$ & $9 \%$ \\
\hline 2009 & $64 \%$ & $22 \%$ & $39 \%$ & $-26 \%$ & $-7 \%$ & $-48 \%$ & $-6 \%$ & $-6 \%$ & $-6 \%$ & $7 \%$ & $7 \%$ & $10 \%$ \\
\hline 2010 & $6 \%$ & $2 \%$ & $3 \%$ & $-21 \%$ & $-5 \%$ & $-58 \%$ & $-9 \%$ & $-8 \%$ & $-8 \%$ & $2 \%$ & $2 \%$ & $3 \%$ \\
\hline 2011 & $23 \%$ & $11 \%$ & $17 \%$ & $-2 \%$ & $-0 \%$ & $-4 \%$ & $13 \%$ & $9 \%$ & $10 \%$ & $4 \%$ & $3 \%$ & $5 \%$ \\
\hline 2012 & $2 \%$ & $0 \%$ & $1 \%$ & $0 \%$ & $0 \%$ & $0 \%$ & $-28 \%$ & $-12 \%$ & $-20 \%$ & $5 \%$ & $2 \%$ & $3 \%$ \\
\hline 2013 & $-12 \%$ & $-2 \%$ & $-6 \%$ & $0 \%$ & $0 \%$ & $0 \%$ & \begin{tabular}{|l|}
$-18 \%$ \\
\end{tabular} & $-1 \%$ & $-1 \%$ & $-20 \%$ & $-3 \%$ & $-5 \%$ \\
\hline 2014 & $49 \%$ & $5 \%$ & $22 \%$ & $0 \%$ & $0 \%$ & $0 \%$ & $-19 \%$ & $-1 \%$ & $-2 \%$ & $-17 \%$ & $-3 \%$ & $-4 \%$ \\
\hline 2015 & $55 \%$ & $13 \%$ & $43 \%$ & $0 \%$ & $0 \%$ & $0 \%$ & $23 \%$ & $11 \%$ & $17 \%$ & $-7 \%$ & $-1 \%$ & $-2 \%$ \\
\hline 2016 & $68 \%$ & $7 \%$ & $16 \%$ & $1 \%$ & $1 \%$ & $3 \%$ & 1 & $1 \%$ & $1 \%$ & $-11 \%$ & $-2 \%$ & $-3 \%$ \\
\hline 2017 & $40 \%$ & $6 \%$ & $11 \%$ & $0 \%$ & $0 \%$ & $1 \%$ & $10 \%$ & $1 \%$ & $2 \%$ & $-8 \%$ & $-2 \%$ & $-3 \%$ \\
\hline 2018 & $31 \%$ & $7 \%$ & $12 \%$ & $-1 \%$ & $-0 \%$ & $-2 \%$ & $14 \%$ & $2 \%$ & $3 \%$ & $-2 \%$ & $-1 \%$ & $-1 \%$ \\
\hline
\end{tabular}

5. táblázat. A jövedelmezöségi mutatóinak alakulása 2008-2018 között, adatok \%-ban

Forrás: Saját szerkesztés a vállalatok éves beszámolói alapján

Az „A” vállalat esetében 2014-ben zárult le a beruházás, ezt követően valamennyi jövedelmezőségi mutató szintje emelkedett. A vetítési alapok az elszámolt támogatás hatására (majdnem 3Mrd Ft-tal) jelentősen növekedtek, különös tekintettel az összes eszközértékre és a saját tőkére, hiszen a támogatási összeg a tárgyi eszközökön keresztül növelte a befektetett eszközértéket, így pedig a teljes eszközértéket, illetve a saját tőke értéke is növekedett a forrás oldalon, mivel a támogatási összeg a tőketartalék javára került elszámolásra. Ennek ellenére történt a jövedelmezőségi mutatók javulásra. 
$\mathrm{Az}$ „E” vállalat esetében a bevétel arányos jövedelmezőség jóval magasabb szintű, 2011-ben 60\% feletti, azaz az értékesítés nettó árbevételének több mint 60\%-a vált üzemi eredménnyé. 2013-tól, a fejlesztési beruházás megvalósulásától kezdődően azonban nem tapasztalható a mutatók javulása, vetítési alaptól függetlenül alacsonyabb jövedelem előállítási képesség mutatkozik. Ennek oka, hogy a vetítési alapok növekedtek a beruházás és a támogatási összeg miatt, azonban ez nem járt együtt a bevételek, ezen keresztül pedig az üzemi (üzleti) tevékenység eredményének növekedésével. Az „F” vállalat esetén a beruházás aktiválásának évében, 2013-ban valamennyi jövedelmezőségi mutató romlott az előző időszakhoz viszonyítva, ennek oka, hogy ebben az évben a vállalat által múködtetett szálloda csökkentett kapacitással üzemelt, illetve nem volt elérhető valamennyi szolgáltatása és a vetítési alapok is növekedtek. A következő években a saját tőke arányos és az árbevétel arányos jövedelmezőségi mutatók értéke több százalékponttal emelkedett, 2016-ban a ROS elérte a 46\%-ot, a ROE pedig a 34\%ot, majd a mutatók értéke alacsonyabb szinten stabilizálódott, de a beruházás előtti időszakhoz viszonyítva mindenképpen javult a vállalat jövedelem előállító képessége. A G" vállalat esetén a beruházás aktiválása később, 2015-ben történt meg, 2014-ig a jövedelmezőségi mutatók tekintetében csökkenés volt látható, majd 2015-től kezdődően mindegyik jövedelmezőségi mutató értéke javult, a vállalatnak sikerült a bevételek növekedése és a hatékonyabb költséggazdálkodás által magasabb üzemi (üzleti) eredményt elérni. A ROS 2018-ban elérte az 57\%-ot, a ROA a 10\%-ot, a ROE mutató pedig a 23\%-ot. A „B” vállalat esetén 2008-ban a jövedelmezőség rendkívül magas volt, majd 2010-tôl jelentős mértékben csökkent, 2011-ben, a beruházás aktiválásának évében a vállalat minden jövedelmezőségi mutatója negatív. Ezt követően pedig egészen 2016-ig a ROS mutató extrém mértékben növekedett, ebben az évben elérte a 68\%-ot, egyértelműen megfigyelhető a szálláshely kapacitás bővítéséből, a nyújtott szolgáltatások minőségének emeléséből adódó pozitív hatás. Bár 2016-ban jelentősen kevesebb üzemi (üzleti) eredményt ért el a vállalat, de a vetítési alapok is nagymértékben csökkentek. A ROA, illetve ROE mutatói is javultak a vállalatnak, majd 2017-től csökkenés tapasztalható.

A további 3 vállalat jövedelmezősége nem javult a támogatással megvalósuló beruházások hatására, annak ellenére, hogy ennek a 3 cégnek összesen 916226752 Ft támogatás került folyósításra. A „C”és „D” vállalat esetében ugyan a beruházással összefüggésben megszűnt a veszteség előállítás, de nagymértékű, a szállásadással, vendéglátással összefüggő bevétel termelődés nem történt. A „H” vállalat esetében a beruházás üzembe helyezésének évétől, 2013-tól kezdődően folyamatosan nagy összegű negatív üzemi (üzleti) eredményt realizál a vállalat.

A jövedelmezőségi mutatók alapján kevésbé versenyképesebbnek minősíthető „C”, „D”, „E” vállalat által megvalósított beruházás közös jellemzője, hogy olyan szolgáltatások kiépítésére irányultak, amelyekre nem volt valós fogyasztói igény, míg szálláshelyek wellness részleg fejlesztésére nem fordítottak megfelelő figyelmet. Annak ellenére, hogy a wellness kínálati elemek iránt egyre növekvő keresletet tapasztalunk az egészségtudatos életmód terjedésével. A wellness kínálati elemek lehetnek például a fürdős szolgáltatások, szaunák, masszázs és egyéb közérzetjavító terápiák, sportprogramok, beauty szolgáltatások, közösségi programok és reformgasztronómia, mely az egészség holisztikus megközelítése értelmében alkalmas az egészség megőrzésére, megtartására (Müller et al., 2006). A wellness elemek kitolják a szezont, növelhetik a vendégek tartózkodási idejét ezzel költéshajlandóságát és nagyobb bevételeket generálnak a szolgáltatók számára és nagyobb realizált üzleti eredményt is, mely a beruházások megtérülésében szerepet játszik. Kiemelendő továbbá, hogy ezeknél a vállalatoknál 
alapvető vállalatirányítási, szervezési, költséggazdálkodási problémák is kiolvashatóak a mérlegből és az eredménykimutatásból. A hosszú távú jövedelmezőség, versenyképesség elérése érdekében a vállalatvezetésnek látnia kell a háttérben meghúzódó okokat és ki kell jelölnie azt az utat, melyet végigjárva az üzletmenetre jellemző problémák kiküszöbölhetőek. A vállalat vezetésének feladata továbbá, hogy tudatosítsa valamennyi munkavállalóban az irányt, e nélkül a hosszú távú siker aligha képzelhető el.

\section{5. Összegzés}

A versenyképességre vonatkozóan nem található egységes megközelítés a szakirodalomban, az ezzel foglalkozó kutatók sokféle formában értelmezik, a versenyképesség különböző szintjeit különböztetik meg. Sokan tartják vállalati szinten értelmezhetőnek a versenyt, mely megközelítés adott iparág versenyképességét alapvetően meghatározza. A vállalati versenyképességet számtalan tényező befolyásolja, megkülönböztethetőek az úgynevezett „puha” és „kemény” tényezők. A „puha” tényezők a számviteli beszámolók alapján nem mérhetőek, míg a „kemény” tényezők a számviteli beszámolókból származó adatokból kiválóan mérhetőek. A „kemény” és a „puha” versenyképességi tényezőket nevezik tangible (megfogható, leírható és mérhető értékekkel kifejezhető vagyon, mint például a gépek, technológia, pénz, föld, raktárkészlet) és intangible (nem megfogható, nem könnyen mérhető, mint például a hírnév, a szervezeti kultúra, a vezetési színvonal, a munkavállalók motiváltsága, a kiváló vevői kapcsolatrendszer) vagyonnak is (CSATH, 2019). Jelen tanulmány célja a magyar gazdaság egyik stratégiai fontosságú ágazatában, a turisztikai szektorban működő 8 vállalatának a versenyképességi vizsgálata a kapott turisztikai célú támogatások tükrében. Az elemzés csak a vállalatok számviteli beszámolóiból, illetve a pályázati nyilvántartásukból kinyert adatok felhasználására korlátozódott és speciálisan a versenyképesség egy részterületét, a jövedelem eloállító képességet vizsgálta. Összességében megállapítható, hogy 8 vállalat által, az Új Széchenyi Terv Fejlesztési Program Északalföldi Operatív Programjának keretében kapott turisztikai célú fejlesztések megvalósítását célszó támogatások nem emelték közvetlenül a vizsgált vállalatok üzemi (üzleti) tevékenységének eredményét, mivel nem az eredmény javára kerültek elszámolásra, hanem a saját tôkén belül, a tőketartalékok között szerepelnek. A jelentős, majdnem 5 Mrd Ft összegű vissza nem térítendő támogatás ellenére a vállalatok jövedelmezőségi mutatói nem javultak jelentősen, sőt három vállalat esetén egyáltalán nem. A „H” vállalat esetén a jövedelmezőség kifejezett romlása következett be a beruházás aktiválásának évétől. Természetes, hogy a beruházás éveiben valamelyest visszaesik az eredményesség, hiszen a vállalatok magára a beruházásra koncentrálnak, mely jelentős költségnövekedéssel, valamint a csökkentett kapacitáson való üzemelés révén pedig csökkenő bevételekkel jár, de ez a negatív jelenség csak időszakos kell, hogy legyen. Abban az esetben, ha a beruházást követő években nem javul a vállalat nyereség előállító képessége, felmerül a kérdés, hogy az adott beruházás megvalósítására ténylegesen szükség volt-e, illetve milyen mélyen meghúzódó okai vannak a vállalat alacsony jövedelmezőségének. Ezeknek az alapvető problémáknak a megoldása nélkül elképzelhetetlen az üzleti siker. 


\section{Hivatkozások}

[1] Adorján Cs. - Bába Á. - Lukács L.- Mikáczó É. - Róth J.(2004): Üzemgazdasági számvitel. Saldó Kiadó, Budapest, 348 p.

[2] Ács P. - Pintér J. (2011): Bevezetés a sportstatisztikába. Dialóg Campus Kiadó-Nordex Kft., Budapest, 145p.

[3] Bíró T. - Kresalek P. - Pucsek J. - Sztanó I.: 2012. A vállalkozások tevékenységének komplex elemzése . Perfekt Kiadó, Budapest, 257 p.

[4] Chikán A. - Czakó E. - Kazainé Ónodi A. (2006): Gazdasági versenyképességünk vállalati nézőpontból - Versenyben a világgal 2004-2006 kutatási program; Zárótanulmány, december In: Somogyi Márta: Versenyképesség a szakirodalomban- A fogalmi megközelítések összegzése és elemzése (I. rész) pp. 54.- 64. In: Vezetéstudomány XL. ÉVF. 2009. 4. SZÁM

[5] Csath Magdolna (szerk.) (2019): A versenyképesség-mérés változásai és új irányai. Dialóg Campus Kiadó, Budapest, pp. 14-50.

[6] Diamond, J. (1977): Tourism's role in economic development: The case re-examined. Economic Development \& Cultural Change, Vol. 25, No.3. pp. 539-553.

[7] Fenyves, V. (2014): Vállalati teljesítményértékelés pénzügyi mutatók és a DEA felhasználásával ACTA SCIENTIARUM SOCIALIUM 40 pp. 133-146. , 14 p.

[8] Fenyves, V. -Bács, Z. - Zéman, Z. - Böcskei, E. - Tarnóczi, T. (2018): THE ROLE OF THE NOTES TO THE FINANCIAL STATEMENTS IN CORPORATE DECISION-MAKING CORPORATE OWNERSHIP AND CONTROL $15: 4$ pp. 138-148.

[9] Hunyadi L. - Vita L. (2008): .Statisztika I., Aula kiadó, Budapest, 348 p.

[10] Kulendran, N. - K. Wilson (2000): “Modelling Business Travel.” Tourism Economics, Vol. 6, No.1. pp. 47-59.

[11] Kresalek P. (2005): A számviteli beszámolók elemzésének egyes elméleti kérdései. Budapesti Gazdasági Főiskola. Budapest, pp. 119-129.

[12] Müller A - Könyves E. (2006): Az egészségturizmus lehetőségei az Észak-alföldi régióban. In: Acta Academiae Pedagogicae Agriensis - Az Eszterházy Károly Főiskola tudományos közleményei. XXX.III. Kötet. pp. 132-144

[13] Somogyi M. (2000): Versenyképesség a szakirodalomban- A fogalmi megközelítések összegzése és elemzése (I. rész) In: Vezetéstudomány XL. ÉVF. 2009. 4. SZÁM. pp. 54.- 64.

$\mathrm{I}_{1}$ : A KSH jelenti. Gazdaság és társadalom.

http://www.ksh.hu/docs/hun/xftp/gyor/jel/jel1803.pdf

letöltés ideje: 2019.12.20.

I $\mathrm{I}_{2}$ : Pályázati közlemények.

https://www.palyazat.gov.hu/ 
letöltés ideje: 2019.12.20.

I $_{3}: \quad$ Porter Michael E. (1990): The Competitive Advantage of Nations.

http://www.economie.ens.fr/IMG/pdf/porter 1990 -

the competitive advantage of nations.pdf

letöltés ideje: 2019.11.29.

I4: $\quad$ EU Pályázatok (2012): Észak-Alföldi Operatív Program. Akcióterv.

https://www.palyazat.gov.hu/doc/2670

letöltés ideje: 2019.12.22. 